\title{
Is community energy really non-existent in post-socialist Europe? Examining recent trends in 16 countries
}

March 2020

Iñigo Capellán-Pérez ${ }^{a, b,}$, , Nadia Johanisova ${ }^{c}$, Jasminka Young ${ }^{d, e}$, Conrad Kunze $^{f}$

aResearch Group on Energy, Economy and System Dynamics. Escuela de Ingenierías Industriales, Paseo del Cauce s/n, University of Valladolid, 47011 Valladolid, Spain

bSystems Engineering and Automatic Control, Escuela de Ingenierías Industriales, Paseo del Cauce $\mathrm{s} / \mathrm{n}$, University of Valladolid, 47011 Valladolid, Spain

'Department of Environmental Studies, Faculty of Social Studies, Masaryk University, Joštova 10, 621 00 Brno, Czech Republic (johaniso@fss.muni.cz)

dPublic Governance Institute, Faculty of Social Sciences, KU Leuven, Parkstraat 45 - bus 3609 - lokal 03.231, B-3000 Leuven, Belgium (jasminka.young@student.kuleuven.be)

eRES Foundation, Zmaja od Noćaja 3a, 11000 Belgrade, Serbia

fCentre of Environmental Studies (FFU), Otto Suhr Institute of Political Science, Freie Universitaet Berlin, Ihnestraße 22, 14195 Berlin, Germany (conrad.kunze2@fu-berlin.de)

*Corresponding autor: inigo.capellan@uva.es.

\section{Abstract}

Community energy (CE) initiatives are developing in many regions of the world through a great diversity of typologies. Europe has a leading role with thousands of ongoing projects of small and medium size, which are however unevenly distributed over the continent. The density of CE projects is highest in North-Western and parts of Central Europe; on the contrary, their spread in postsocialist European countries (PSECS) has been reported to be much more limited. However, the (under)development of CE in PSECs remains an understudied topic in the literature. In this paper, we present an exploratory overview of the situation and briefly discuss its potential explanatory factors for 16 PSECs. We find differing development levels of progress, with Croatia outstanding with a diversity of projects and a certain maturation of the field, the Czech Republic, Hungary, Poland, Slovakia and Slovenia with a reduced number of rather small-scale projects, while in the remaining countries no operational relevant projects have been found to date. We present our methods, overviews by country and some tentative explanations. We suggest further research to be directed towards in-depth analysis of single countries and relevant project cases in PSECs.

Key-words: community energy; post-socialist Europe; RES cooperatives; renewable energies.

\section{Cite this paper as:}

Capellán-Pérez, I., Johanisova, N., Young, J., Kunze, C., 2020. Is community energy really non-existent in post-socialist Europe? Examining recent trends in 16 countries. Energy Research \& Social Science 61, 101348. https://doi.org/10.1016/j.erss.2019.101348 


\section{Table of contents}

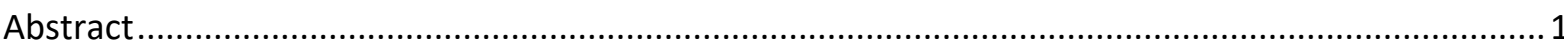

Contenido

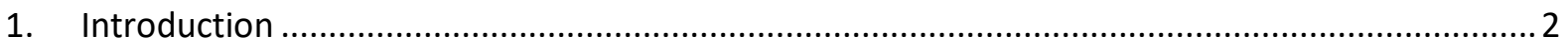

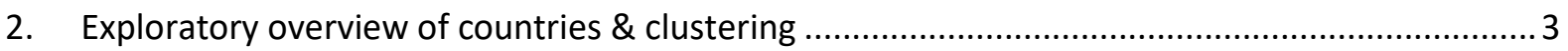

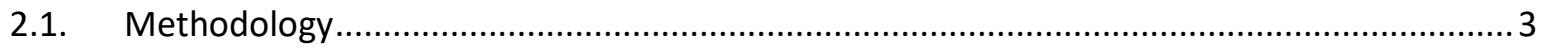

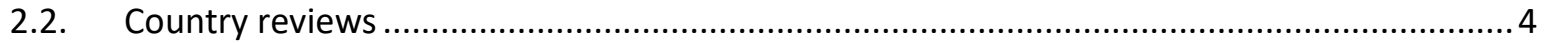

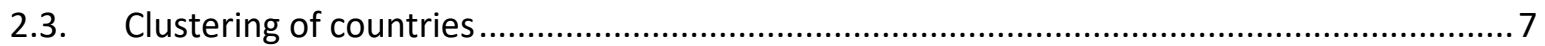

3. Discussion and recommendations for further work ............................................................ 8

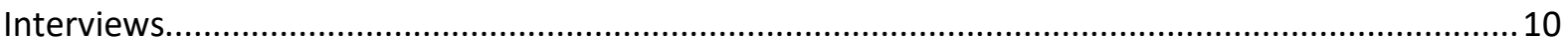

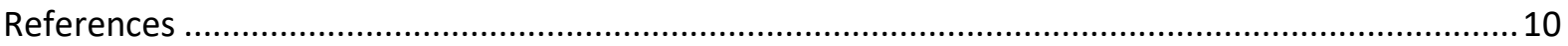

\section{Introduction}

In the era of climate change and fossil fuel depletion, renewable energy sources (RES) also offer a key transformative potential from a social point of view due to their modularity and capacity to generate energy at a local level, allowing for the development of local, democratic and participative bottom-up initiatives. The collective ownership of RES allows for the democratization of the access to capital investments in means of energy production, and opens the sector to broader participation in comparison to other sectors. Community Energy (CE) has the potential to contribute more than a technological fix towards reducing carbon emissions. It is potentially a socially transformative economic approach with various benefits for communities, democratic participation and local economies [1-5].

RES cooperatives and publicly-owned municipal utilities are the two most common collective alternatives to traditional ownership structures [6-8]. These organizations mostly perform three functions: i.e., generation, distribution and retailing of RES, usually in the form of electricity, although examples also exist for heating and transport. RES cooperatives tend to have more participatory decision-making processes, while municipal utilities often espouse a more top-down form of management, though they remain under the control of a democratic entity - the municipality. Participatory management and non-profit ownership are among the building blocks of a new economy, needed for transition to post-growth societies [9]. RES cooperatives with a great diversity of typologies are growing in numbers and production capacity in many regions of the world, such as in the US and Latin America, and more recently also in South-East Asia and Africa. $[8,10]$ Europe has a leading role in the field with over 3,000 organizations reported as RES cooperatives and even more CE projects. However, these are mostly concentrated in the so-called "EU-15" (which corresponds with the European Union before its enlargement from 2004 onwards) and in the closely aligned countries: Switzerland and Norway $[7,11,12]$. They have a high concentration in Northern and Western Europe (Denmark, the Netherlands, Belgium, Germany, Austria, Northern Italy, Sweden, the UK and France), and are also developed, although to a lesser degree, in Spain and Southern Italy. On the contrary the literature reports an almost complete absence of CE and RES cooperatives in post-socialist European countries (PSECS). For example, the European Federation of RES Cooperatives website maps only 3 projects in the PSECs ( 2 in Croatia and 1 in Slovenia) [12]. The knowledge is however uncertain, as few studies are available on the topic $[7,13,14]$. 
Even though there is no mono-causal explanation for addressing the differences in the level of development of CE in different countries, apparent key factors appear to be the historical influence of the ecological and anti-nuclear movements, the spread of publicly-owned municipal utilities, the impact of the oil shocks in the 1970s and the derived policy-responses, and more generally the particular socio-political-cultural context of post-socialist countries (PSEC), in particular a widespread mistrust of the co-operative institutional structure, born out of its misuse by the establishment during the socialist era [11]. The specificities of PSEC's particular socioeconomic regime during the cold-war era as well as of their transition to market economies in the 1990s seem particularly relevant $[15,16]$.

This perspective article presents insights which shed light on the current situation of CE and RES cooperatives in PSECs. Our research consists of a collation of information from a diversity of sources (scientific and grey literature, research projects under development, interviews with key informants and homepages) for 16 countries. We found a situation that is far from homogenous, with a spectrum of countries from those with emerging trends towards CE to others where such developments were not discernible.

\section{Exploratory overview of countries \& clustering}

\subsection{Methodology}

Given the perils of oversimplification and generalizing when explaining the current low incidence of CE in PSECs, with literature on the topic quite scarce $[7,13]$, and uncertainty about the membership of new and/or small organizations in the European federation REScoop.eu [12], we decided to perform an exploratory overview at a country level. The following three steps were applied with the aim of performing a clustering of the development level of CE and RES cooperatives in PSECs:

1. Definition of the boundaries of the analysis: in relation to the geographical scope and the type of organizations to be considered as CE.

2. An overview of the situation using a common set of criteria.

3. Classification of countries in clusters according to their level of CE development.

The geographical coverage of the research was focused on PSECs with three exceptions: inclusion of post-soviet countries such as Baltic states given that they currently belong to the EU, the exclusion of Moldova for which it was not possible to find information, and exclusion of East Germany given its specific case of national unification. Hence, a total of 16 countries were covered (in alphabetical order): Albania, Bosnia and Herzegovina, Bulgaria, Croatia, Czech Republic, Estonia, Hungary, Macedonia, Montenegro, Latvia, Lithuania, Poland, Romania, Serbia, Slovakia and Slovenia. Projects included in the review had to be operational by January 2019.

In our search for CE and RES cooperatives in each country, we focussed on organisations fulfilling the following two criteria $[4,17,18]$ :

- Structure: collective legal ownership and democratic governance. Organisational structures that emphasize participation and make use of collective legal ownership, a collective benefit allocation mechanism, or collective decision-making processes. Democratic and localised ownership and governance patterns.

- Ethics: having other-than-profit goals. I.e., entities having a relevant "normative" or "political" motivation beyond profit (although not excluding it).

Hence, different organizational structures such as cooperatives or municipalities may fulfil these criteria. RES technologies include modern scalable technologies such as wind, solar PV, biomass and mini-hydro (excluding large hydro). 


\subsection{Country reviews}

Information was retrieved from a diversity of sources, such as research projects (CO-POWER [19], ENERGISE [20], BioVill ${ }^{1}$ ), CE networks (RESCoop.eu, Energy-Democracy.net) and 3 personal interviews with key informants. This was complemented by field visits undertaken in Croatia (to two RES cooperatives in May 2017) and Serbia (to 21 municipalities in June 2017).

\section{Croatia}

CE projects in Croatia gained speed and relevance coinciding with the EU accession process and its culmination in EU membership in 2013. This was preceded by preparatory work which focused on sharing the best practices from the EU countries and the use of available funds for local renewable energy and energy efficiency development projects. A rising external energy dependency [22] and a rich local renewable energy base [23] combined to advance CE in the country [24,25].

The national portal for energy efficiency [26] reports eight existing RES cooperatives (see Table 1). These RES cooperatives grew within the context of European integration, and with strong support from the national United Nations Development Programme (UNDP) for bottom-up initiatives. The Croatian cooperatives are led by a number of enthusiastic local actors as in most parts of the world, and UNDP's funds are helping to make the step from vision to reality. Among the first established is the one on the island of Krk (Energetska zadruga 'Otok Krk'), founded in 2012. Krk is the only Croatian island with a formal strategic document that envisions $100 \%$ RES use by 2030 [27] and possibly the only such plan in the whole PSEC region [25]. Via this process, and especially after Croatia became an EU member in 2013, the availability of funds for projects of the RES type increased significantly (Interviews 1 and 2). Local level entities such as municipalities and in some cases public utilities play an active role in a number of these projects through promotion, cofinancing, co-ownership, contribution in kind (such as providing roofs of the public buildings for rooftop PV) expertise and so on [25,28,29].

Table 1: List of operating RES cooperatives in Croatia and year of creation. "*" indicates that this cooperative was the subject of a field visit. Source: ENU [26].

\begin{tabular}{|l|l|}
\hline Name & Established \\
\hline BAN-UNION & Unknown \\
\hline Energetska zadruga 'Otok Krk' & $2012^{*}$ \\
\hline Zelena energetska zadruga (ZEZ) & $2013^{*}$ \\
\hline Braniteljska zadruga Ka-Solar & 2012 \\
\hline
\end{tabular}

1 "The objective of the BioVill project is to transfer and adapt experiences gained in countries where bioenergy villages already exist (Germany and Austria) to countries with less examples in this sector (Slovenia, Serbia, Croatia, Macedonia and Romania). The project fosters the development of the bioenergy sector in selected target countries by strengthening the role of locally produced biomass as a main contributor for energy supply on local level, considering opportunities of market uptake or expansion for local farmers, wood producers or SMEs" [21]. 


\begin{tabular}{|l|l|}
\hline Energetska zadruga Kastela & 2013 \\
\hline Energetska zadruga Lug & 2013 \\
\hline Energetska zadruga Suncani Hvar & After 2013 \\
\hline Energetska zadruga SPES & 2002, but registered for RES in 2013 \\
\hline
\end{tabular}

However, our field visit in 2017 to the Island of Krk confirmed that there are still many limiting factors hampering CE potential in Croatia. These include a long permission process, a legal barrier to become a prosumer, and delay in implementing net-metering due to the absence of implementing legislation (Interview 1; [30,31]). The development of RES continues to be burdened by a strategic and political focus on fossil fuels [32], lack of diversification efforts in the RES sector, as well as by slow implementation of RES policy due to the existing legislative and administrative barriers, despite recent advances (late 2018) such as the greater variety of possible legal forms or the start of implementation of the long awaited net-metering [25]. For example, EZ Otok Krk still does not produce or sell renewable energy and they have focused their activity in promotion of RES local and decentralized models, educational and advocacy activities, roof cadastre, etc., besides getting ready for production and retailing in the coming future.

At the same time, bottom-up initiatives led by local actors have continued, with the most recent one coordinated by the Zelena Energetska Zadruga that led to the first successful CE crowdfunding campaign in Croatia, in the city of Križevci in 2018. Citizens invested in a PV rooftop power plant on a public building by providing a 10 -year loan with a $4.5 \%$ annual interest rate and the amount earned through the sale of surplus electricity is to be used to repay the loans to investors (Interview 2; [28]). There are also cogeneration projects in some municipalities but in that respect, they don't differ from those that are developing in some other PSECs as public private partnerships.

\section{Czech Republic}

As of 2019 there are no RES cooperatives in the Czech Republic defining themselves as such, though there may be flat owners in one building for, example, teaming up to purchase photovoltaic panels. However, according to a Czech RES expert (interview 3), there are about 45 RES plants owned by municipalities, most of them focused on biomass heating (see also [33,34]). Even very small municipalities in the Czech Republic have full legal status, own land and premises and democratically elect their local representatives who have considerable decision-making authority. Many of these, based in very small municipalities, might thus qualify as CE organisations. Well-known examples include a biomass heating plant in Hostětín, using woodchip from local forests, and a complex biogas-and-biomass heating and electricity generating system in Kněžice near Nymburk. Both villages have less than 500 inhabitants. While the number of municipal RES projects is now stagnating for lack of government support, there are hopes this might change with the emergence of EU support under the new EU directive (2018/2001) "on the promotion of the use of energy from renewable sources".

\section{Hungary}

A number of small-scale CE projects operate in Hungary, subject to significant barriers $[35,36]$. These projects, of which none is a RES cooperative, are born out of existing organised communities such as social cooperatives, community supported agriculture schemes or ecological building networks, 
which are thinking of enlarging their portfolio. Non-government groups such as Friends of the Earth and grassroots initiatives such as Transition Wekerle are also involved in various local RES projects and energy saving initiatives [37]. For example, in the Budapest garden-city-type suburb of Wekerle, Transition Wekerle (Átalakuló Wekerle) have initiated home insulation workshops and developed an Energy efficiency and renewable energy plan which was subsequently accepted by the local council [38]. Kunze and Becker [7] have reported a succesful project to reduce energy poverty in a marginalised Roma village through the self-transformation of agricultural waste from local farms into biomass briquettes. As in the Czech Republic, there are also municipal initiatives, often funded by the EU. An example would be the community biomass heating plant in Pornóapáti, using local woodchip [39]. In the Pitvaros village, a complex programme of introducing solar collectors, heat pumps, biomass boilers and thermal insulation systems for public buildings was initiated by the local municipalities (Zöldenergia hasznosítás Pitvaros területén). In a wind farm project in Vép funded by (partly local) ethical investors, the investors handed over $20 \%$ of the ownership to the local municipality and have created conditions for locals to become co-owners [39].

\section{Poland}

Poland suffers from very strong economic-political carbon lock-in due to the dependence on domestic coal. Coal constitutes around $80 \%$ of the country's energy production and around $50 \%$ of the total primary energy supply [40]. This makes Poland the EU-27 country with the highest emission intensity of its energy production [41]. This context translates into very challenging conditions for RES deployment in general and for cooperatives and community initiatives in particular. Nevertheless, there are still some fragile projects to be found. The cooperative Spóldzielnia Nasza Energia in the district of Zamość, initiated in 2014 by a local company and several municipalities has a democratic one-member-one-vote structure and operates a network of biogas stations. According to its statutes it aims to support local farmers [42]. However, a recent review concluded that this project "seems to be an initiative arising from the business sector, rather than a bona fide citizens' movement" [13]. Another RES cooperative, Polska Spóldzielnia Energetycna, is registered in Bielsko Biala, but it is doubtful if it still operates. The municipality of Kisielice combines wind, photovoltaics and a biomass heating plant and claims to be an energy self-sufficient community in terms of both heating and electricity [43]. Only recently, in June 2018, has Polish law begun to recognise energy cooperatives as legal entities on their own. Since 2016, the government has begun to promote "energy clusters"- a contract between different units (individuals, legal persons, business entities, research entities and local municipalities), for the purpose of energy generation, balancing, trade or distribution. There are more than 33 such clusters in operation (they require government approval to operate), mainly focused on energy saving and support of local economies, but a very limited number involve RES and citizen participation [13].

\section{Slovakia}

We do not know of any renewable cooperatives in Slovakia who define themselves as such, although some biogas plants may be owned by agricultural co-operatives (the situation is similar in the Czech Republic). However, Slovakian agricultural co-operatives date from the socialist period and have usually not internalised any ethical or ecological goals. As in the Czech Republic and Hungary, there is a variety of municipal RES projects in Slovakia. These include small hydro (e.g. in the village Necpaly) and local biomass. The non-government organisation Friends of the Earth CEPA has been supporting municipal initiatives and cooperation regarding renewable resources for many years [44] For example, with their support, eight small municipalities in the Banská Bystrica region founded a 
consortium in 2005 (Bioenergia Bystricko) focused on collaboration in expanding local biomass heating potential (woodchip from municipal forests) for public buildings and building their own biomass production capacities [45]. Other smaller consortia are being formed.

\section{Slovenia}

REScoop.eu maps one functioning cooperative in the country: Zadruga sončnih elektrarn Slovenije (ZSES, http://zses.si/), which has some community projects on biomass district heating ${ }^{2}$ and aims at promoting self-consumption photovoltaics among members [12]. A small cooperative hydropower plant exists in Krajcarca in Gorenjska, and there are some examples of district heating with biomass, which do not have a cooperative structure, but the engagement of the local community in the project is obvious, such as the project of district heating with biomass in Vransko. Other projects are in the pipeline, such as a solar energy cooperative to be owned by local citizens and other local stakeholders in Nova Gorica, also aiming at raising awareness about energy efficiency and energy self-sufficiency [46]. As in the rest of the PSUC region, the existing projects have had to surmount significant administrative barriers and not favourable legislation. Additional information can be found in Karba \& Tkalec [47].

\section{$\underline{\text { Rest of PSECS }}$}

For the rest of the PSECs, no operational relevant projects fulfilling our 2 criteria in terms of structure (collective legal ownership and democratic governance) and ethics (having other-thanprofit goals) as of January 2019 were found in the checked bibliography [14,33,39,48,49]. It should be noted that municipalities have, in some cases, initiated and managed RES projects, however with generally a weak relationship between these and the host communities. This is the case of Romania [49-51], where out of dozens of solar PV projects in rural areas only two were initiated and are managed by the local authorities without any explicit inclusion of local citizens: the majority of projects deployed were designed and implemented rather unilaterally by outside investors, typically private companies with no strong links to local communities. The BIOVILL project [21] represents another example of RES deployment (bioenergy) at municipal level in different PSEC countries (Croatia, Macedonia, Romania, Serbia and Slovenia) which do not include organisational and management structures that emphasise public participation or make use of collective legal ownership, a collective benefit allocation mechanism, or collective decision-making processes. Despite these projects lacking these social features at the origin, they still represent an opportunity to bring RES closer to local representatives and citizens, and could trigger further technical and social innovations locally in the future.

\subsection{Clustering of countries}

Table 2 organizes all the reviewed countries in 3 clusters as a function of the development level of CE fulfilling our 2 criteria in terms of structure (collective legal ownership and democratic governance) and ethics (having other-than-profit goals). The relative "density" of projects with relation to population has also been considered (e.g., Croatia has almost 10 times less population than Poland). We can categorize PSECs in three broad categories: (A) those with a diversity of projects presenting a more mature field (Croatia), (B) those with a reduced number of rather smallscale CE projects (Czech Republic, Hungary, Poland, Slovakia and Slovenia), and (C) those were no

2 District heating is any system for distributing heat generated in a centralized location through a system of insulated pipes for residential and commercial heating requirements such as space heating and water heating. Not to be confused with district as regional administrative unit. 
operational relevant projects as of January 2019 were found (Albania, Bosnia and Herzegovina, Bulgaria, Estonia, Latvia, Lithuania, Macedonia, Montenegro, Romania, Serbia). Of course, there may be projects that we have overlooked. Our clustering should therefore be regarded as work in progress.

Table 2: Clustering of post-socialist European countries (PSECS) with relation to the development of CE (as of June 2018)

\begin{tabular}{|l|l|}
\hline Cluster & Countries \\
\hline \multirow{3}{*}{$\begin{array}{l}\text { A- Diversity of projects; } \\
\text { more mature field }\end{array}$} & Croatia \\
\hline \multirow{4}{*}{$\begin{array}{l}\text { B- Reduced number } \\
\text { and rather small-scale } \\
\text { projects }\end{array}$} & Czech Republic \\
\cline { 2 - 2 } & Hungary \\
\cline { 2 - 2 } & Soland \\
\cline { 2 - 2 } C- No relevant projects & Slovakia \\
\cline { 2 - 2 } & $\begin{array}{l}\text { Slbania, Bosnia and Herzegovina, Bulgaria, Estonia, Latvia, Lithuania, } \\
\text { Macedonia, Montenegro, Romania, Serbia. }\end{array}$ \\
\hline
\end{tabular}

\section{Discussion and recommendations for further work}

Community energy (CE) has a great potential to contribute to a transition towards a democratic, sustainable and decentralised energy system. CE is a very diverse phenomenon, with the participation of a large range of actors and articulated in a variety of organizational and participatory schemes across the globe. While there is a large and growing literature on CE itself, a broad review of its form and geographical extent is generally lacking. In fact, most scientific literature on CE overwhelmingly focuses on specific projects or countries in North-Western Europe [13]. Although it is true that countries such as Denmark, Germany or the Netherlands concentrate a high share of these projects and organizations, their development and even existence in other parts of the world in general and of Europe in particular remain understudied or even unknown. This is the case of post-socialist European countries (PSECs). These are often subsumed under one label, as in [7]: "In Eastern and Central Europe, though, there are still only very few noteworthy energy-democracy projects", or summarily dismissed: "CE in its various forms is embedded everywhere in Europe except in the former communist countries of the center and east of the continent" [13]. However, as our overview shows, these affirmations are partially distorted by the lack of awareness of projects and organizations in PSECs among the research scholars focusing on CE. At least partially, this low visibility is due to a lack of publicly available information -at least in other languages than the vernacular- on CE projects in PSECs, which, as we try to show here, is dispersed in an amalgam of grey literature, news, reports and community websites.

Different levels of CE development in the PSECs have been found. Croatia stands out with a diversity of projects presenting a more mature field, while in the Czech Republic, Hungary, Poland, Slovakia and Slovenia some CE projects are found, with a limited and rather small-scale scope. There is a majority of PSEC countries (10/16) for which no operational CE projects fulfilling our 2 criteria in terms of structure (collective legal ownership and democratic governance) and ethics (having other- 
than-profit goals) have been found as of January 2019. However, this is a highly dynamic process as seen from recent news (summer 2019) of the registration of the first renewable energy cooperative in Serbia in the municipality of Šabac ${ }^{3}$ or the successful crowdfunding campaign of "Solarna Pecka" in Bosnia-Herzegovina aiming to bring a clean and sustainable solar energy to Pecka village through a citizen's community direct engagement and financing model. ${ }^{4}$ Similarly, the policy landscape is also changing, e.g., the recently passed legislation on pro(summers) in Romania including net metering. The heterogeneous development level of CE across different PCECs implies that a diversity of explanatory factors exists for their different levels development which are beyond the usual and general arguments of discreditation of the "cooperative" form after the collapse of socialist regimes and a less affluent population $[11,15]$. In particular, the Croatian case seems relevant given that CE in this country seems to be no less developed than in some West European countries such as Portugal ${ }^{5}$ or Ireland $[7,14]$, thus putting in doubt the often assumed "West-East" and "North-South" divides with relation to CE distribution in Europe.

A number of pilot projects and studies were commissioned in Croatia in the early 2010s to assess the RES potential of smaller geographical and administrative configurations, such as islands, district, towns and local communities $[24,25]$. While hydropower potential is close to fulfilment and wind power is growing fast, these studies revealed a large and underutilised solar potential [23]. The solar potential is linked geographically to the islands and the coast, which are in a greater need of decentralised CE solutions also because the peak consumption during the tourist season coincides with the highest solar irradiance. The dependence on imported energy combined with their geography, solar potential, uneven consumption due to an intensive tourist season and a relatively positive approach towards community models seem to incentivize CE initiatives on Croatian islands $[22,25]$. Many have fund-raised for some community projects (Interview 2). However, there are still many limiting political and legal factors hampering CE potential in Croatia, including pressures from the regime which perpetuate the lock-in on fossil fuels as the Krk case shows [25,32]. Further research should be directed to shed light on the development level of these RES cooperatives in the country.

Although some historically recent socio-economic elements are common to all the PSECs, namely state socialism followed by a quick transition to market economies in the 1990s, there are also many differences -historical, cultural, geographical, economic and political. Even under socialism, policies differed. Yugoslavia developed an original self-management system where cooperatives played a very different role than in its contemporary socialist countries [53], however the implications for an eventual easier acceptance of the cooperative model in former Yugoslav republics are not clear. Also, the post-socialist transition to market economies varied significantly, -including incidence of war and conflict in some cases. The former German Democratic Republic (GDR) also represents a particular case due its history of national reunification. Moreover, the current level of CE there seems rather comparable to Western and Central Europe than to the PSECs studied $[7,54,55]$.

3 Slobodan Jerotić, Šabac municipality. Panel 'Clean energy for us' organised by RES Foundation within the Conference on Renewable Energy Sources organized by the French Institute in Belgrade (Serbia) on 19-20 June, 2019. Muzej Jugoslovenske Kinoteke Beograd.

4 https://www.indiegogo.com/projects/solarna-pecka\#/

5 "The only Community Energy (EC) that exists in Portugal is Coopérnico (https://www.coopernico.org), the other 4 RES co-op that are registered in REScoop.eu, are small wind farms with little impact on the development of renewable energy. Coopérnico presents projects in several parts of the country which contributed to the small increase of levels of consumption of RE, but unfortunately still plays a marginal role in the energy market." Personal communication from Susana Soeiro (17-7-2019). See also Soeiro and Ferreira Dias [52]. 
Further research may explore the possible impact of past and current institutional frameworks (e.g., level of trust in the cooperative form) and local contexts (e.g., coal mining areas of Brandenburg and Saxony) on differences in the distribution of CE in both parts of Germany. Hence, subsuming all the studied countries under the one category of "post-socialist" blurs the many differences between them. The region under review comprises over 120 million people spanning over 2,000 km NorthSouth and over 1,000 km East-West. In addition to their socio-economic and political histories, legal and technical aspects are also likely to be relevant in explaining different levels of CE development between the PSECS and the rest of Europe.

Experiences like the new wave of Spanish RES cooperatives and the case of the Croatian island of Krk [25] show that regime opposition (i.e. legal and structural barriers) can be overcome by strong social, activist and participative engagement [56]. In fact, socio-cultural values are also a key aspect. For example, Kovačić and Dolenec [57] found lower political engagement of youth in East European countries in relation to West European countries as a response to the global financial crisis 2008-09 and the following years. Another potential factor may be the eventual lower environmental awareness in PSECs, which may in some cases be due to a lower income [58], although it should be kept in mind that sustainability-orientation of the population is a multi-dimensional construct affected by more factors than material prosperity $[59,60]$. For the time being, it seems that environmental conflicts have not managed to morph into "creative projects" around CE/RES coops in the region [61].

Based on our preliminary findings, we strongly encourage scholars from PSECs to analyse CE developments in their countries in depth in order to increase knowledge, and enable fruitful comparative analysis as well as relevant policy recommendations. Core questions to be answered include the identification of key actors, the role of historical and institutional factors (path dependency, the local governance structure, etc.), the influence of policy frameworks (e.g., existence of feed-in-tariffs that guarantee long-term payments), the mode of governance of potential CE initiatives and the features of policy process and change. A fertile avenue of future research opens, which can help to identify and discuss specific barriers as well as the potential and opportunities for the flourishing of CE in PSECs.

\section{Interviews}

Interview 1: Edo Jerkic, renewable energies consultant, Croatia (3-1-2019)

Interview 2: Zoran Kordić, Director of ZEZ, Croatia (3-1-2019)

Interview 3: Karel Polanecký, Czech renewable energy expert (20-11-2018)

\section{Acknowledgements}

We thank Laura Zvončeková, Katarína Zuntychová and Agnieska Buchtová for surveys of relevant Slovakian, Hungarian and Polish-language websites, respectively. We thank Susana Soeiro for sharing the preliminar results of her overview of Community Energy in Portugal. The authors also gratefully thank Tomislav Tkalec, Sorin Cebotari and Miklós Antal for comments and feedback during the writing process.

Iñigo Capellán-Pérez acknowledges financial support from a Juan de la Cierva Research Fellowship of the Ministry of Economy and Competitiveness of Spain (no. FJCl-2016-28833). 


\section{References}

[1] S. Barca, Energy, property, and the industrial revolution narrative, Ecol. Econ. 70 (2011) 13091315. https://doi.org/10.1016/j.ecolecon.2010.03.012.

[2] B. Huybrechts, Social Enterprise, Social Innovation and Alternative Economies: Insights from Fair Trade and Renewable Energy, Altern. Econ. Spaces New Perspect. Sustain. Econ. (2013) 113-130.

[3] N. Johanisova, S. Wolf, Economic democracy: A path for the future?, Futures. 44 (2012) $562-$ 570. https://doi.org/10.1016/j.futures.2012.03.017.

[4] C. Kunze, S. Becker, Collective ownership in renewable energy and opportunities for sustainable degrowth, Sustain. Sci. (2015) 1-13. https://doi.org/10.1007/s11625-015-0301-0.

[5] F. Schneider, G. Kallis, J. Martínez-Alier, Crisis or opportunity? Economic degrowth for social equity and ecological sustainability. Introduction to this special issue, J. Clean. Prod. 18 (2010) 511-518. https://doi.org/10.1016/j.jclepro.2010.01.014.

[6] S. Becker, C. Kunze, Transcending community energy: collective and politically motivated projects in renewable energy (CPE) across Europe, People Place Policy. 8 (2014) 180-191.

[7] C. Kunze, S. Becker, Energy democracy in Europe: A survey and outlook, Rosa Luxembg. Stift. Bruss. Off. (2014). https://www.rosalux.eu/publications/energy-democracy-in-europe/.

[8] REN21, Renewables 2016. Global Status Report., REN 21, Paris, 2016.

[9] M. Lewis, P. Conaty, The resilience imperative: Cooperative transitions to a steady-state economy, New Society Publishers, 2012.

[10] ILO, Providing clean energy and energy access through cooperatives, International Labour Office Cooperatives Unit (COOP) Green Jobs Programme, Geneva, Switzerland, 2013.

[11] B. Huybrechts, S. Mertens, The Relevance of the Cooperative Model in the Field of Renewable Energy, Ann. Public Coop. Econ. 85 (2014) 193-212. https://doi.org/10.1111/apce.12038.

[12] REScoop, REScoop.eu map, European Federation of Renewable Energy Cooperatives, https://www.rescoop.eu/community-energy-map (Retrieved 20-4-2019), 2019.

[13] R. Hewitt, N. Bradley, A. Baggio Compagnucci, C. Barlagne, A. Ceglarz, R. Cremades, M. McKeen, I. Otto, B. Slee, Social Innovation in Community Energy in Europe: A Review of the Evidence. Front, Front. Energy Res. 7 (2019) 31. https://doi.org/10.3389/fenrg.2019.00031.

[14] REScoop, REScoop.eu webpage, European Federation of Renewable Energy Cooperatives, https://rescoop.eu/ (Retrieved 10-10-2016), 2019.

[15] T. Bauwens, B. Gotchev, L. Holstenkamp, What drives the development of community energy in Europe? The case of wind power cooperatives, Energy Res. Soc. Sci. 13 (2016) 136-147. https://doi.org/10.1016/j.erss.2015.12.016.

[16] V. Beckmann, I.M. Otto, T. Tan, Overcoming the legacy of the past? Analyzing the modes of governance used by the Polish agricultural producer groups, Agric. Econ. 61 (2015) 222-233.

[17] N. Johanisova, E. Frankova, Eco-Social Enterprises, in: C.L. Spash (Ed.), Routdlege Handb. Ecol. Econ. Nat. Soc., Routledge, Abingdon, 2017: pp. 507-516.

[18] J. Young, M. Brans, Analysis of factors affecting a shift in a local energy system towards $100 \%$ renewable energy community, J. Clean. Prod. 169 (2017) 117-124. https://doi.org/10.1016/j.jclepro.2017.08.023.

[19] ENERGISE, COMMUNITY POWER project webpage, https://www.communitypower.eu/en/, 2019.

[20] ENERGISE, ENERGISE project webpage, http://www.energise-project.eu/, 2019.

[21] BioVill, BioVill project webpage, www.biovill.eu, 2019.

[22] IEA, IEA World Energy Statistics and Balances, IEA/OECD, Paris (France), 2019.

[23] Ministarstvo zaštite okoliša i energetike, Nacrt prijedloga Strategije energetskog razvoja Republike Hrvatske do 2030. s pogledom na 2050. godinu (Draft Energy Strategy 2030), Ministarstvo zaštite okoliša i energetike, Zagreb (Croatia), 2019. https://esavjetovanja.gov.hr/ECon/MainScreen?entityld=10936. 
[24] E. Jerkić, L. Jerkić, Z. Kordić, I. Rajšl, I. Grozdanić, Prelazak Hrvatske na 100\% obnovljivih izvora energije. Analiza mogućnosti korištenja obnovljivih izvora energije u Republici Hrvatskoj, Greenpeace in zentral und osteuropa, Zagreb (Croatia), 2015.

[25] J. Young, M. Brans, What does it take to commence a local energy transition in a post-socialist country - evidence from Croatia?, Rev. (2019).

[26] ENU, Energetske Zadruge, Nacionalni Portal Energetske Učinkovitosti, https://www.enu.hr/eeu-hrvatskoj/tko-je-tko-ee-rh/energetske-zadruge/ (Retrieved 17-6-2019), 2019.

[27] igr-IfaS, Interdisciplinarna strategija nulte emisije stakleničkih plinova za integrirani održivi razvoj otoka Krka, Hrvatska, igr d.o.o., Zagreb, Croatia / igr AG, Rockenhausen, Germany \& Institut für angewandtes Stoffstrommanagement (IfaS), Umwelt-Campus Birkenfeld, Germany, Zagreb (Croatia), 2012. https://www.grad-krk.hr/.

[28] ZEZ, ZEZ.coop webpage, Zelena Energetska Zadruga, https://www.zez.coop/en (Retrieved 1010-2019), 2019.

[29] M. Đukan, M. Vajdić, M. Kirac, R. Pašičko, T. Medić, A. Lucić, D. Miletić, I. Szekeres, E. Jerkić, F. Brničević, Priručnik za osnivanje energetskih zadruga, Heinrich Böll Stiftung Hrvatska, 2013. https://bib.irb.hr/datoteka/828110.energetske_zadruge_2.pdf.

[30] A.-M. Boromisa, Renewable Energy Policy in Croatia, Renew. Energy Law Policy Rev. 7 (2016) 81-84.

[31] A.-M. Boromisa, Energy transition in Croatia - Moving towards effective membership in the Energy Union, Institute for Development and International Relations (IRMO), Zagreb, 2018.

[32] Re:Common, Looting 2.0. Supporting state capture at the Krk gas terminal, Re:Common \& Friends of the Earth Croatia, 2019. https://www.counter-balance.org/looting-2-0-supportingstate-capture-at-the-krk-gas-terminal/.

[33] CO-POWER, CO-POWER webpage, Community Power, www.communitypower.eu (Retrieved 21-4-2019), 2019.

[34] P. Němcová, Co přineslo využívání obnovitelnỳch zdrojŭ energie českỳm obcím?: souhrnná zpráva o zkušenostech venkovskỳch obcí vlastnících zařízení na produkci elektřiny a tepla z obnovitelnỳch zdrojŭ energie, Trast pro ekonomiku a společnost, Brno, Czech Republich, 2010.

[35] T. Csoma, Az energiatermelő közösségek jelene és jövője Magyarországon, Master Thesis Eötvös Loránd Univ. (2017).

[36] M. Antal, How the regime hampered a transition to renewable electricity in Hungary, Environ. Innov. Soc. Transit. (2019). https://doi.org/10.1016/j.eist.2019.04.004.

[37] K. Zuntychová, Interview to Alexa Botar, Hungarian activist, Interview Katarina Zuntychová. (2018). https://mtvsz.hu/kozossegi_energia.

[38] Transition Network, Átalakuló Wekerle - Transition Wekerle, Transit. Netw. (n.d.). https://transitionnetwork.org/transition-near-me/initiatives/atalakulo-wekerle-transitionwekerle/ (accessed July 25, 2019).

[39] ENERGISE, Deliverable 2.1. Catalogue of existing good practicies examples of programmes and interventions, European Network for Research, Good Practice and Innovation for Sustainable Energy, 2017.

[40] Ü. Şahin, Carbon lock-in in Turkey: A comparative perspective of low carbon transition with Germany and Poland, Istanbul Policy Centre and Mercator Stiftung, 2018. http://ipc.sabanciuniv.edu/publication/turkiyede-karbon-kilitlenmesi-dusuk-karbona-gecistealmanya-ve-polonya-ile-karsilastirmali-bir-perspektif/?lang=en.

[41] IRENA, Renewable energy prospects for the European Union: Preview for Policy Makers, 2018. https://www.irena.org/publications/2018/Feb/Renewable-energy-prospects-for-the-EU.

[42] Inkubatorbioalians, The first Polish energy cooperative was born (in Polish), Inkubatorbioalins, http://inkubatorbioalians.pl/bez-kategorii/powstala-pierwsza-w-polsce-spoldzielniaenergetyczna/ (retrieved 14/6/2019), 2019. http://inkubatorbioalians.pl/bezkategorii/powstala-pierwsza-w-polsce-spoldzielnia-energetyczna/ (accessed June 14, 2019). 
[43] Ekonomie spoleczna, Ekonomie spoleczna webpage, Ekonomie spoleczna, http://ekonomiaspoleczna.org.pl/ (retrieved 14/6/2019), 2019. Ekonomie spoleczna (accessed June 14, 2019).

[44] FoE, Friends of the Earth Slovakia webpage, Priatelia Zeme, http://cepa.priateliazeme.sk/ (retrieved 14/6/2019), 2019.

[45] Bioenergia Bystricko, Bioenergia Bystricko webpage, Združenie obcí Bioenergia Bystricko, http://www.bioenergiabystricko.sk/, 2019.

[46] ENERGISE, Deliverable 2.5. Production of 30 national summary briefs, European Network for Research, Good Practice and Innovation for Sustainable Energy, 2018.

[47] R. Karba, T. Tkalec, Skupnostno upravljanje z življenjskimi viri (Community-Based Management of Life resources), Časopis Za Krit. Znan. Domišljijo Novo Antropol. J. Crit. Sci. Imagin. New Anthropol. 46 (271) (2018) 165-182.

[48] C. Ball, The Transformation of the Energy Sector and "Citizen Energy “: Insights from Germany with Comments on the Lithuanian Context, Soc. Transform. Contemp. Soc. 3 (2015) 6-13.

[49] S. Cebotari, Against All Odds. Community-owned Renewable Energy Projects in North-West Romania, ACME Int. J. Crit. Geogr. 18 (2019) 513-28.

[50] S. Cebotari, J. Benedek, Renewable Energy Project as a Source of Innovation in Rural Communities: Lessons from the Periphery, Sustainability. 9 (2017) 509. https://doi.org/10.3390/su9040509.

[51] S. Cebotari, M. Mihály, Towards a Progressive Local Development Approach: Insights from Local Community Initiatives in Hungary and Romania, in: T. Lang, F. Görmar (Eds.), Reg. Local Dev. Times Polarisation Re-Think. Spat. Policies Eur., Springer Singapore, Singapore, 2019: pp. 253-285. https://doi.org/10.1007/978-981-13-1190-1_11.

[52] S. Soeiro, M. Ferreira Dias, Energy cooperatives in southern European countries: Are they relevant for sustainability targets?, Energy Rep. (2019). https://doi.org/10.1016/j.egyr.2019.09.006.

[53] F.B. Singleton, B. Carter, The economy of Yugoslavia, Taylor \& Francis, 1982.

[54] T. Moss, S. Becker, M. Naumann, Whose energy transition is it, anyway? Organisation and ownership of the Energiewende in villages, cities and regions, Local Environ. 20 (2015) 15471563. https://doi.org/10.1080/13549839.2014.915799.

[55] C. Kunze, H. Busch, The Social Complexity of Renewable Energy Production in the Countryside, Electron. Green J. 1 (2011). https://escholarship.org/uc/item/18p5h0fh (accessed November 5, 2019).

[56] I. Capellán-Pérez, Á. Campos-Celador, J. Terés-Zubiaga, Renewable Energy Cooperatives as an instrument towards the energy transition in Spain, Energy Policy. 123 (2018) 215-229. https://doi.org/10.1016/j.enpol.2018.08.064.

[57] M. Kovačić, D. Dolenec, Youth Participation in Eastern Europe in the Age of Austerity, in: Young People Re-Gener. Polit. Times Crises, Palgrave Macmillan, Cham, 2018: pp. 375-394. https://doi.org/10.1007/978-3-319-58250-4_20.

[58] A. Franzen, R. Meyer, Environmental Attitudes in Cross-National Perspective: A Multilevel Analysis of the ISSP 1993 and 2000, Eur. Sociol. Rev. 26 (2010) 219-234. https://doi.org/10.1093/esr/jcp018.

[59] M. Domazet, D. Marinović Jerolimov, eds., Sustainability perspectives from the European semiperiphery, Institute for Social Research (Zagreb, Croatia), Heinrich Boell Stiftung Hrvatska, 2014.

[60] A. Scheidel, L. Temper, F. Demaria, J. Martínez-Alier, Ecological distribution conflicts as forces for sustainability: an overview and conceptual framework, Sustain. Sci. (2017) 1-14. https://doi.org/10.1007/s11625-017-0519-0.

[61] J. Špirić, Ecological distribution conflicts and sustainability: lessons from the post-socialist European semi-periphery, Sustain. Sci. (2017) 1-16. https://doi.org/10.1007/s11625-017-05056. 
